\title{
Red Cell Distribution Width as a Marker of Inflammation in Type 2 Diabetes Mellitus
}

\author{
HANAN M. AHMED, M.D.; MOSTAFA A. HARIDI, M.D.; MANAL E. EL-DEEN, M.D. and \\ TAGHREED G. MADANI, M.D.
}

The Department of Internal Medicine, Faculty of Medicine, Assiut University Hospital, Assiut, Egypt

\begin{abstract}
Background: Red Blood Cell Distribution (RDW) is recognized as a global marker of chronic inflammation.

Aim of Study: To study the relation between RDW and complications in patients with type 2 diabetes mellitus and its relation to CRP.

Methods: The study included 70 patients with type $2 \mathrm{DM}$ and 20 healthy controls with clinical and laboratory data including HbA1c, RDW and C Reactive Protein (CRP).

Results: Patient group showed 65 (92.85\%) of them had macrovascular and $64(91.42 \%)$ patients had microvascular complications. When we compared patients with macrovascular and microvascular complications to control group we found high RDW in those with vascular complications than control group ( $p=0.001)$. There was a significant difference between RDW in patients with macrovascular complications in comparison to those without macrovascular complications ( $p$ value $=0.02$ ). There was a significant difference between $\mathrm{RDW}$ in patients with nephropathy compared to those with retinopathy.

Conclusion: In our study, we confirmed a strong relation between diabetics with vascular complications and RDW.
\end{abstract}

Key Words: DM - Microvascular complication - Macrovascular complication $-R D W-C R P$.

\section{Introduction}

DIABETES mellitus is a group of metabolic disorders characterized by hyperglycemia which results from either defect in insulin secretion, insulin action, or both.

Chronic hyperglycemia of diabetes mellitus is associated with long term damage, dysfunction, and failure of different organs, especially the eyes, kidneys, nerves, heart and blood vessels [1] .

Correspondence to: Dr. Taghreed G. Madani, The Department of Internal Medicine, Faculty of Medicine, Assiut University Hospital, Assiut, Egypt
The primary cause of mortality in diabetic patients is Cardiovascular Diseases (CVD) [2] while major cause of morbidity is microvascular complications [3]

Detection of markers for macrovascular and microvascular disease could supply new data about pathogenesis of diabetic complications which may help early diagnosis and help to take decisions in terms of prevention and treatment.

Red cell distribution width is a measure of variation in size of circulating erythrocytes (anisocytosis) [4] which is routinely obtained in standard Complete Blood Cell counts (CBC) without more costs and has been used in differential diagnosis of anemia.

The normal value of RDW is ranging between (11.5 and $14.5 \%$ ), while higher values indicate greater variations in cell sizes [4]

$R D W$ is as follows:

- RDW-SD 39-46 fL [5].

- RDW-CV 11.6-14.6\% in adult [6].

High RDW indicate the presence of anisocytosis which is related to impairment of erythropoiesis and degradation of erythrocytes [4], reflecting chronic inflammation and increased level of oxidative stress.

Elevated RDW is reported on complete blood count, marked anisocytosis (increased variation in red cell size) is expected on peripheral blood smear review. Many researchers have suggested the relationship between RDW and diabetes-associated complications and investigated whether there is any association between RDW, nephropathy, neuropathy and Peripheral Arterial Disease (PAD) in a type 2 diabetic population [7] . 
One of the markers that have recently received considerable attention for its role in diabetes is RDW. RDW is a quantitative measure of the heterogeneity circulating red blood cell size, and is normally assessed in the differential diagnosis of anemia [8] RDW is effectively a free test that, is reported beside a complete blood count without extra cost by well prognostic value [7]. So this study of RDW and type 2 diabetes in order to evaluate capability of RDW as a novel prognostic marker in diabetic patients.

High RDW indicate the presence of anisocytosis which is related to impairment of erythropoiesis and degradation of erythrocytes [4]. Reflecting chronic inflammation and increased level of oxidative stress [9].

However the underlying biological mechanism remain unclear. RDW is recognized as global marker of chronic inflammation and oxidative stress. [10].

There was strong and independent association of RDW level with risk of all-cause and Cardiovascular $(\mathrm{CV})$ mortality in patients with Cardiovascular Disease (CVD) [11]. And in the general population [12].

However the relationship between RDW and macrovascular complication of DM was not investigated in any studies, moreover no published data were reported on the relationship between RDW and microvascular complication in diabetic patients, [13].

\section{The aim of the study:}

To study the relation between RDW and vascular complications in patients with type 2 diabetes mellitus and its relation to other inflammatory marker as CRP.

\section{Patients and Methods}

This study is a cross-sectional study, conducted on 70 patients with type 2 diabetes mellitus and 20 healthy controls. Selected from Internal Medicine Department at Assiut University Hospital and Endocrinology Out Patient Clinic, from March 2016 to March 2017.

\section{Inclusion criteria:}

Type 2 diabetes mellitus with micro and/or macrovascular complications.

\section{Exclusion criteria:}

- Type 1 diabetes mellitus.
- Type 2 diabetes mellitus without microvascular or macrovascular complications.

- Type 2 diabetes mellitus with acute complications like Diabetic Ketoacidosis (DKA) or acute illness (cold, flu, diarrhea, vomiting, pneumonia or ear infections within the last month).

- Chronic illness such as congestive heart failure or chronic liver disease.

- All aneamic patient with $\mathrm{Hb}$ level less than 13 excluded from our study.

All patients and were subjected to the following:

- Full history and clinical examination for all participants age, sex, and smoking with special emphasis on duration of diabetes, diabetic medication, and complications of diabetes.

- Study their anthropometric characteristics by measuring their weight, height and calculating BMI.

- Patients assessed as regards presence or absence of diabetic microvascular complications.

- Fundus examination was done to detect retinopathy. (Cotton wall spots, flame shaped, haemorragic dot, vitrous haemorrage and maculopathy).

- Laboratory investigations:

- Sample collection and laboratory investigations: After an overnight fast of 14 hours venous blood samples were drawn under complete aseptic conditions as follows:

A- $2 \mathrm{ml}$ of blood were drawn on K3EDTA vaccutainer for complete blood count using automated cell counter Cell Dyn 3700 from Abbott USA.

B- $6 \mathrm{ml}$ blood for separation of serum. Samples were centrifuged $(3,000 \mathrm{~g}$ for $10 \mathrm{~min}$.), serum was separated. Serum blood glucose, urea, creatinine and complete lipograme as well as glycated haemoglobin were measured by using automated COBAS INTEGRA 400 (from Boehringer MannheimGermany).

- Renal function test (blood urea, serum creatinine).

- Urine analysis for proteinuria and detection of micro albuminuria using $\mathrm{A} / \mathrm{C}$ ratio.

- Fasting blood glucose, 2 hours post prandial blood glucose.

- Lipid profile: Total cholesterol, LDL, HDL and Triglycerides (TGs). 
Total cholesterol, LDL, HDL and triglycerides (TGs):

- Cholesterol fasting level (Normal level is $\leq 200$ $\mathrm{mg} / \mathrm{dl})$.

- LDL-C fasting level (normal level is $\leq 130 \mathrm{mg} / \mathrm{dl}$ ).

- HDL-C level (normal level is $27-83 \mathrm{mg} / \mathrm{dl}$ ).

- Triglycerides fasting level (normal level is 50$200 \mathrm{mg} / \mathrm{dl}$ ).

Were done by standard laboratory methods using (modular auto analyzer).

- Measurement of CRP: The reference range for $\mathrm{C}$-reactive protein is as follows:

- CRP: 0-10mg/L.

- High-sensitivity CRP (hs-CRP): <3mg/L.

- Measurement of RDW: The reference range for RDW is as follows:

- RDW-SD 39-46 fL.

- RDW-CV 11.6-14.6\% in adult.

- Reference ranges may vary depending on the individual laboratory and patient's age.

- HBA 1c.

- Patients assessed as regards presence or absence of diabetic macrovascular complications as cardiovascular examination, Resting Electrocardiogram (ECG).

\section{Statistical analysis:}

The collected data will be analyzed statistically using IBM-SPSS Version 20. Continuous data will be expressed in form mean \pm SD and analyzed by using student $t$-test while nominal data will be expressed in form of frequency and proportion and compared by Chi square test.

Correlation of RDW with other variables in our study will be tested by using Pearson's correlation. Multivariate regression analysis will be used to determine different risk factors for diabetic complications in the study. The chi-Square test was used to compare qualitative data. The level of significance was taken as the $p$-value of $\leq 0.05$.

\section{Ethical consideration:}

Written consent form before starting the study. Confidentiality was assured for all patients.

\section{Results}

The study aimed to assess the relation between RDW and complications in patients with type 2 diabetes mellitus and its relation to other inflammatory marker as CRP. It included 70 patients had type $2 \mathrm{DM} ; 65$ (92.85\%) patients had macrovascular and $64(91.42 \%)$ patients had microvascular complications with 20 healthy subjects control. Control selected from Internal Medicine Department at Assiut University Hospital and Endocrinology Outpatient Clinic.

Part I:Demographic and laboratory data of all subjects included in the study (Tables 1A-C).

Mean age of the study group was $61.51 \pm 8.57$ years, $42(60 \%)$ patients were male. Mean duration of DM was $9.96 \pm 6.03$ years; $35(50 \%)$ patients were on oral hypoglycaemic, $34(84.6 \%)$ on insulin therapy while in only one patient DM was controlled by oral hypoglycaemic and insulin (Table 1A).

In the study group $39(55.7 \%)$ patients had hypertension that was controlled on therapy, 7 (10\%) patients had CKD (Table 1A).

Table (1B) showed the clinical characteristics of the study group. There was no significant statistical difference between both group respecting hemoglobin level, platelets count, TLC, MCV, $\mathrm{MCH}, \mathrm{LDL}, \mathrm{HDL}$ and TG level where $p$-value was $>0.05$. In contrast there was significant difference between both group regarding urea, creatinine, cholesterol, CRP, RDW, FBS and 2h-PP where $p$ value was $<0.05$ (Table 1C).

It was noted that albuminuria presented in 60 (85.7\%) patients; $28(40 \%)$ patients had microalbuminuria while $32(45.7 \%)$ had macroalbuminuria. Also; $40(57.16 \%)$ patients had $\mathrm{Hb}$ A1c more than $7 \%$ while only $30(42.80 \%)$ patients that had $\mathrm{Hb} \mathrm{A} 1 \mathrm{c}$ less than 7\% (Table 1C).

Part II: Frequency of macrovascular and microvascular complications in the study.

Our study showed that 60 patients had both macrovascular and microvascular complications while microvascular complications presented in 64 patients and 65 patients had macrovascular complications. Only one patient didn't have complications (Table 2) and Fig. (1). Sixty patients had IHD; five of them had history of CVS. Thirty three patients had nephropathy, 31 had retinopathy while both were presented in 28 patients (Table 2) and Fig. (1).

It was noticed that those with either macrovascular or microvascular complications had more RDW level compared to control with significant $p$-value (0.00) (Table 3 ). 
ANOVA test showed that RDW was different significantly between different types of macrovascular and microvascular complications with $p$ value were $<0.05$ (Table 4 ).

The test was followed by Post-Hoc Tukey test to show difference between each type of complications and others. Regarding microvascular vascular; it was noticed that patients with nephropathy had high significant level of RDW in comparison with those with retinopathy and neuropathy ( $p=$ 0.00 and 0.01 respectively) (Table 4 ).

Table (5) showed that there was significant statistical difference between mean of RDW in those patients with nephropathy in compared to

Table (1A): Demographic data of all subjects of the study.

\begin{tabular}{lccc}
\hline Variables & \multicolumn{3}{c}{ Study group } \\
& \multicolumn{1}{c}{$\begin{array}{c}\text { Control group } \\
(\mathrm{n}=70)\end{array}$} & $\begin{array}{c}p \text { - } \\
\text { value }\end{array}$ \\
\hline Age (years) & $61.51 \pm 8.57$ & $43.35 \pm 9.93$ & 0.00 \\
Sex: & & & \\
$\quad$ Male & $42(60 \%)$ & $11(55 \%)$ & 0.44 \\
$\quad$ Female & $28(40 \%)$ & $9(45 \%)$ & \\
Body mass index $\left(\mathrm{kg} / \mathrm{m}^{2}\right)$ & $26.63 \pm 2.62$ & $25.45 \pm 2.88$ & 0.88 \\
Smoking: & & & \\
$\quad$ Yes & $8(11 \%)$ & $2(10 \%)$ & 0.09 \\
$\quad$ No & $62(89 \%)$ & $18(90 \%)$ & \\
\hline
\end{tabular}

Data was expressed in form of mean \pm SD or frequency (percentage). $p$-value was considered significant if $<0.05$. those with retinopathy with $p$-value was 0.00 . Also, those with IHD had high level of RDW in compared to those with CVS with $p$-value was 0.00 .

Table (1B): Clinical characteristics of the diabetic patients.

\begin{tabular}{ll}
\hline Characteristics & Frequency (\%) \\
\hline $\begin{array}{l}\text { Duration of diabetes mellitus } \\
\text { Type of therapy: }\end{array}$ & $9.96 \pm 6.03$ \\
Oral hypoglycaemic & $35(50 \%)$ \\
Insulin & $34(48.6 \%)$ \\
Both & $1(1.4 \%)$ \\
Hypertension: & \\
Yes & $39(55.7 \%)$ \\
Mean duration (years) & $7.11 \pm 4.44$ \\
No & $41(44.3 \%)$ \\
Other comorbidities: & \\
Nothing & $60(85.7 \%)$ \\
Chronic kidney disease & $7(10 \%)$ \\
Mean duration (years) & $1.5 \pm 0.98$ \\
Cerebrovascular stroke & $5(7.1 \%)$ \\
$\begin{array}{l}\text { Clinical characteristics: } \\
\text { Diabetic neuropathy: }\end{array}$ & \\
Pain & \\
Numbness & $12(17.14 \%)$ \\
Cardiac characteristics: & $20(28.57 \%)$ \\
Chest pain & \\
Previous catheter (diagnostic angio) & $14(20 \%)$ \\
Previous ischemia & $10(14.28 \%)$ \\
Diabetic retinopathy: & \\
Loss of vision & \\
Flashes of light & $0(0 \%)$ \\
Presbyopia & $3(4.28 \%)$ \\
- Nominal data was expressed in form of frequency $(\%) \mathrm{while}$ \\
continuous one was in form of mean \pm SD.
\end{tabular}

Table (1C): Laboratory data of all subjects in the study.

\begin{tabular}{|c|c|c|c|c|}
\hline Variables & & $\begin{array}{l}\text { Study group } \\
\qquad(\mathrm{n}=70)\end{array}$ & $\begin{array}{l}\text { Control group } \\
\qquad(n=20)\end{array}$ & $\begin{array}{c}p- \\
\text { value }\end{array}$ \\
\hline Complete blood picture: & $\begin{array}{l}\text { Hemoglobin }(\mathrm{g} \%) \\
\text { Platelets }(\mathrm{X} 10) \\
\text { Total leucocytes } \\
\text { Mean corpuscular volume } \\
\text { Mean corpuscular hemoglobin }\end{array}$ & $\begin{array}{l}13.46 \pm 1.33 \\
287.75 \pm 61.81 \\
8.75 \pm 3.62 \\
87.60 \pm 8.80 \\
30.99 \pm 2.62\end{array}$ & $\begin{array}{l}13.25 \pm 1.59 \\
282.98 \pm 74.65 \\
9.61 \pm 4.35 \\
86.40 \pm 4.69 \\
29.65 \pm 2.34\end{array}$ & $\begin{array}{l}0.99 \\
0.56 \\
0.08 \\
0.65 \\
0.98\end{array}$ \\
\hline Kidney functions: & $\begin{array}{l}\text { Creatinine }(r m a l / 1) \\
\text { Urea }(m a / 1)\end{array}$ & $\begin{array}{l}206.49 \pm 148.62 \\
17.14 \pm 12.02\end{array}$ & $\begin{array}{l}81.00 \pm 29.79 \\
5.64 \pm 3.69\end{array}$ & $\begin{array}{l}0.00 \\
0.00\end{array}$ \\
\hline Albuminuria: & $\begin{array}{l}\text { No } \\
\text { Micro albuminuria } \\
\text { Macro albuminuria }\end{array}$ & $\begin{array}{l}10(14.3 \%) \\
28(40 \%) \\
32(45.7 \%)\end{array}$ & & \\
\hline Lipid profile: & $\begin{array}{l}\text { Cholesterol }(\mathrm{mg} / \mathrm{dl}) \\
\text { Triglyceride }(\mathrm{mg} / \mathrm{dl}) \\
\text { High density lipoprotein }(\mathrm{mg} / \mathrm{dl}) \\
\text { Low density lipoprotein }(\mathrm{mg} / \mathrm{dl})\end{array}$ & $\begin{array}{l}197.62 \pm 37.63 \\
160.9 \pm 48.73 \\
58.5 \pm 20.52 \\
80.56 \pm 38.79\end{array}$ & $\begin{array}{l}178.15 \pm 40.07 \\
145.25 \pm 38.42 \\
67.37 \pm 17.48 \\
78.42 \pm 46.04\end{array}$ & $\begin{array}{l}0.04 \\
0.19 \\
0.08 \\
0.83\end{array}$ \\
\hline Glucose tolerance test: & $\begin{array}{l}\text { Fasting blood glucose }(\mathrm{mmol} / \mathrm{l}) \\
2 \text { h-post prandial glucose }(\mathrm{mmol} / \mathrm{l})\end{array}$ & $\begin{array}{l}7.6 \pm 1.94 \\
10.68 \pm 4.04\end{array}$ & $\begin{array}{l}4.64 \pm 0.82 \\
5.69 \pm 0.82\end{array}$ & $\begin{array}{l}0.00 \\
0.00\end{array}$ \\
\hline HbAlc: & $\begin{array}{l}<6 \% \\
6-7 \% \\
>7 \%\end{array}$ & $\begin{array}{l}10(14.28 \%) \\
20(28.56 \%) \\
40(57.16 \%)\end{array}$ & & \\
\hline CRP & CRP & $16.59 \pm 13.75$ & $2.71 \pm 1.12$ & 0.00 \\
\hline RDW & RDW & $14.91 \pm 1.86$ & $12.06 \pm 1.46$ & 0.00 \\
\hline
\end{tabular}

Data was expressed in form of mean \pm SD and $p$-value considered of statistical difference if $<0.05$. 
Table (2): Frequency of diabetic complications in the study group.

\begin{tabular}{|c|c|c|c|c|c|c|c|}
\hline & \multicolumn{3}{|c|}{$\begin{array}{l}\text { Macrovascular } \\
\text { complications } \\
(n=65)\end{array}$} & \multicolumn{3}{|c|}{$\begin{array}{l}\text { Microvascular } \\
\text { complications } \\
\quad(\mathrm{n}=64)\end{array}$} & \multirow{2}{*}{$\begin{array}{c}\text { Both } \\
\text { macrovascular and } \\
\text { microvascular } \\
\text { complications }\end{array}$} \\
\hline & $\begin{array}{l}\text { IHD } \\
\text { only }\end{array}$ & $\begin{array}{l}\text { CVS } \\
\text { only }\end{array}$ & Both & $\begin{array}{c}\text { Nephropathy } \\
\text { only }\end{array}$ & $\begin{array}{c}\text { Retinopathy } \\
\text { only }\end{array}$ & Both & \\
\hline Frequency & 60 & 0 & 5 & 33 & 31 & 28 & 60 \\
\hline
\end{tabular}

Data was expressed in form of frequency.

IHD: Ischaemic Heart Disease.

CVS: Cerebrovascular Stroke.

Table (3): RDW in those patients with complications and control.

\begin{tabular}{lcccc}
\hline & Frequency & $\begin{array}{c}\text { RDW } \\
(\text { Mean } \pm \text { SD) }\end{array}$ & $95 \%$ CI & $p$-value \\
\hline Macrovascular complications & 65 & $15.05 \pm 1.84$ & $2.89-3.88$ & 0.00 \\
Control & 20 & $12.07 \pm 1.46$ & & \\
Microvascular complications & 64 & $14.98 \pm 1.91$ & $1.99-3.84$ & 0.00 \\
Control & 20 & $12.08 \pm 1.46$ & & \\
\hline
\end{tabular}

RDW : Red Cell Distribution ration.

SD : Standard Deviation.

$p$-value was significant if $<0.05$.

Table (4): RDW in different types of complications.

\begin{tabular}{lcccc}
\hline & Frequency & $\begin{array}{c}\text { RDW } \\
\text { (Mean } \pm \mathrm{SD})\end{array}$ & $95 \% \mathrm{CI}$ & $p$-value \\
\hline Microvascular complications*: & & & & \\
$\quad$ Nephropathy & 61 & $14.15 \pm 1.43$ & $2.21-4.23$ & 0.00 \\
$\quad$ Retinopathy & 59 & $13.18 \pm 1.65$ & & \\
Neuropathy & 53 & $10.20 \pm 1.33$ & & \\
Macrovascular complications $*:$ & & & & 0.00 \\
$\quad$ Ischemic heart disease & 65 & $15.65 \pm 1.11$ & $1.23-1.99$ & \\
$\quad$ Peripheral vascular disease & 23 & $13.08 \pm 1.14$ & & \\
$\quad$ Cerebral vascular stroke & 5 & $11.23 \pm 1.89$ & & \\
\hline
\end{tabular}

RDW : Red Cell Distribution ration.

SD : Standard Deviation.

$p$-value was significant if $<0.05$.

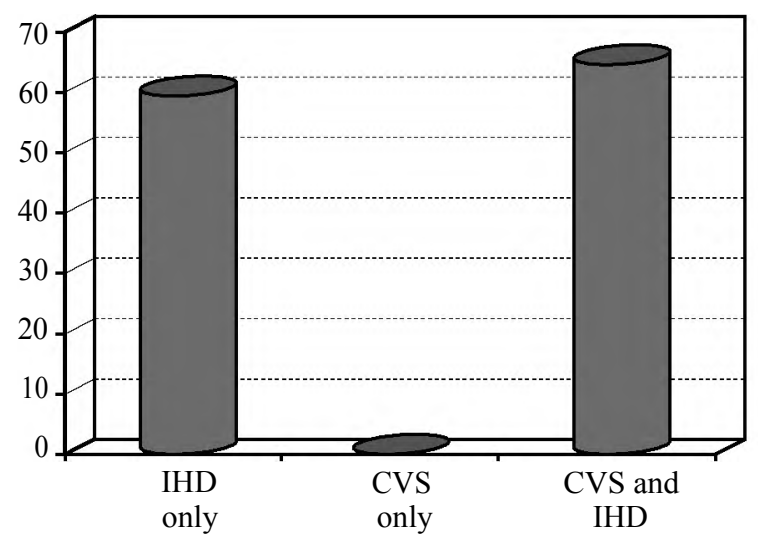

Macrovascular complications

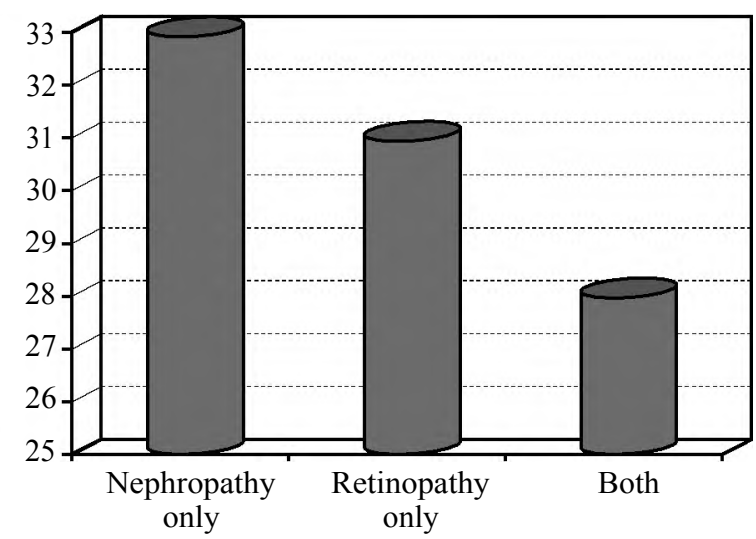

Microvascular complications

Fig. (1): Frequency of diabetic complications in the study group. 


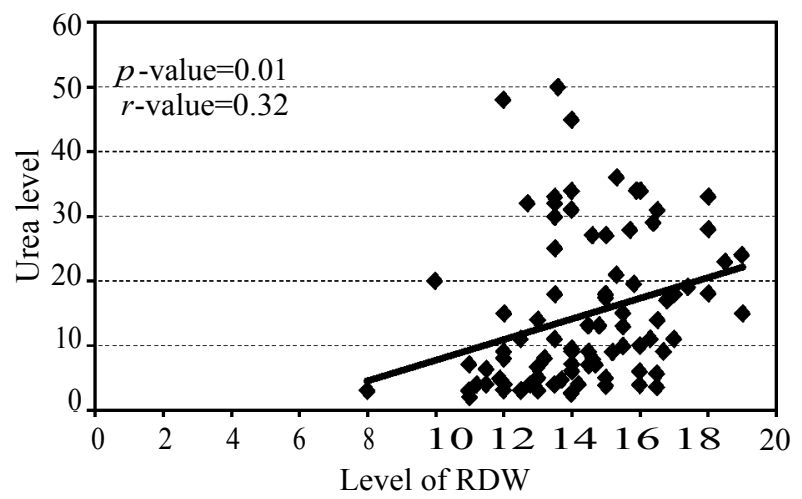

Fig. (2A): Correlation between RDW and blood urea nitrogen.
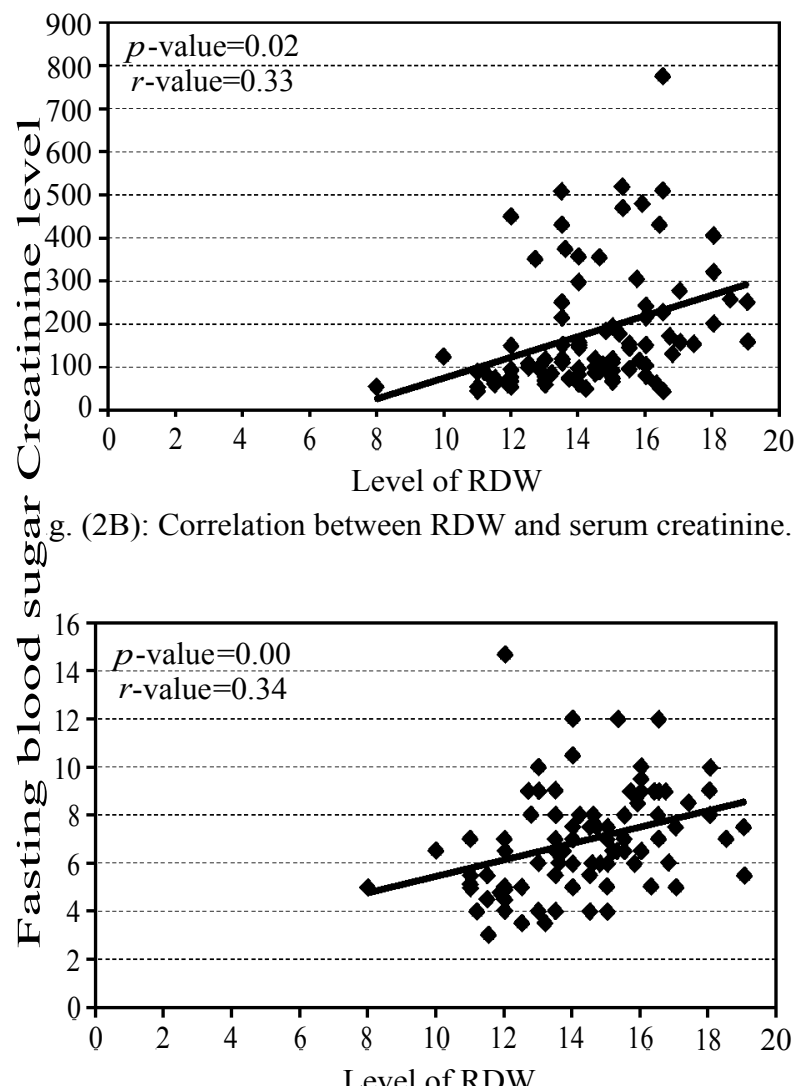

Fig. (2C): Correlation between RDW and fasting blood sugar.

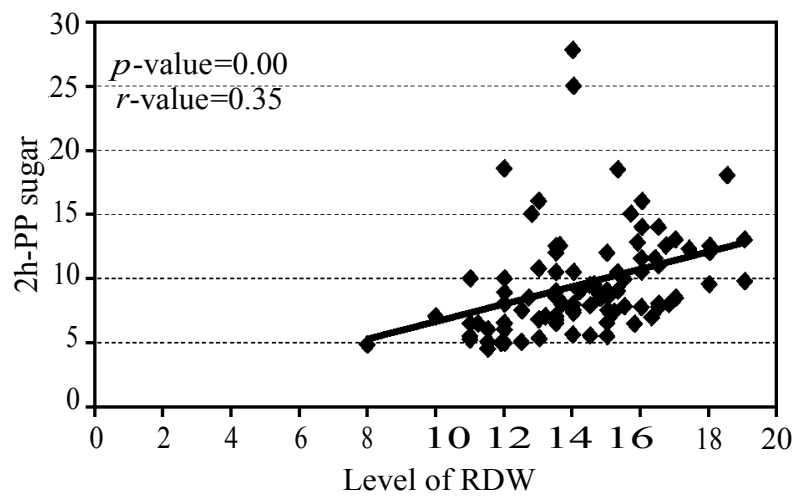

Fig. (2D): Correlation between RDW and $2 \mathrm{~h}$ post prandial sugar.

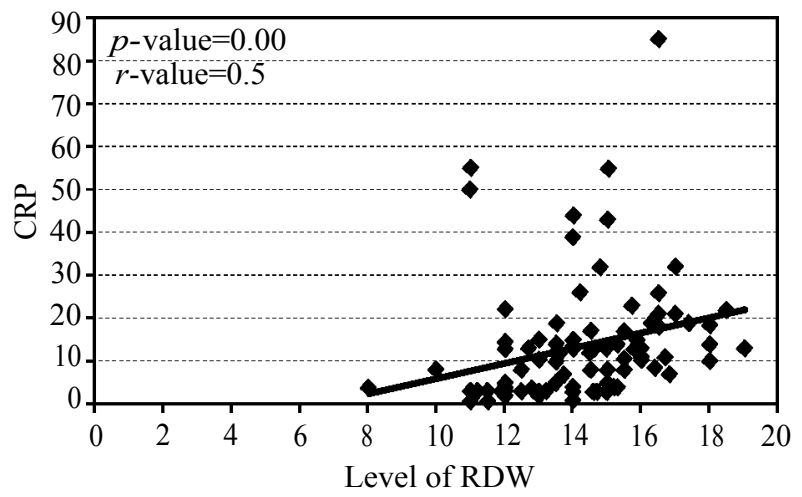

Fig. (2E): Correlation between RDW and C-reactive protein.

\section{Discussion}

All forms of diabetes increase the risk of longterm complications. These typically develop after many years [10-20], but may be the first symptom in those who have otherwise not received a diagnosis before that time. Red cell Distribution Width (RDW) is a parameter that measures variation in red blood cell size or red blood cell volume. RDW is elevated in accordance with variation in red cell size (anisocytosis).

Elevated RDW is reported on complete blood count, marked anisocytosis (increased variation in red cell size) is expected on peripheral blood smear review.

The study showed significant difference between diabetic and control groups regarding urea, creatinine, cholesterol, CRP, RDW, FBS and $2 \mathrm{~h}$ PPBS with $p$-value was $<0.05$. Those results were in agreement of Magri \& Fava [14] who proved that increase in RDW indicates the presence of anisocytosis (variation in size of the circulating erythrocytes) related to defect of erythropoiesis and decay of erythrocytes and reflecting increased levels of oxidative stress, both of which are signs in type 2 diabetics. This study was in concomitant with other studies suggested that RDW increased with CRP in the study group compared to control group and theses findings were concomitant with authors who suggested that RDW could be an significant predictor of vascular complications of diabetes mellitus Cakir Lutfullah, et al. [15]

Also Magri \& Fava [14] stated that RDW is considered a predictive marker that may reflect an underlying inflammatory process and it is relation to other inflammatory marker like high sensitivity C-Reactive Protein (hs-CRP). Inflammation may effect on erythropoiesis, circulatory half life and deformability of erythrocytes and thus elevating RDW levels.Supporting these findings Kim et al., 
[16] postulated that Inflammation could lead to release of immature red blood cells into the peripheral circulation. Many studies confirm among myocardial infarction patients, that elevated RDW is associated with stroke occurrence (Ani \& Ovbiagele [17]. So this marker can be applied as a prognosticator for macrovascular and microvascular complications of diabetes mellitus Sherif et al., [18].

There was a significant difference between RDW in patients with macrovascular complications as compared to those without macrovascular complications $(p$-value $=0.02)$. It was noticed that those with either macrovascular or microvascular complications had more RDW level compared to control with significant $p$-value $(0.00)$.

The findings of this study were in agreement with Lee, [19] who stated that chronic vascular inflammation may play a role in the development of macrovascular complications in diabetic patients.

Also Malandrino et al., [12] suggest that RDW has a role as a predictive marker of macrovascular complications in diabetes mellitus. As they recommended, diabetic patients with raised level of RDW required close monitoring of risk factors as (dyslipidemia, hypertension and albuminuria).

Also the study showed a significant statistical difference between mean of RDW in those patients with nephropathy compared to those with retinopathy with $(p$-value $=0.00)$. Also, those with IHD had high level of RDW in compared to those with CVS with $(p$-value $=0.00)$. These were in agreement with Malandrino et al., [12] who repoted that RDW was significantly associated with increased longterm all-cause mortality in diabetic patients after a mean follow-up duration of 3.9 years. In addition, data from the National Health and Nutrition Examination Survey (NHANES) have shown that higher RDW levels are associated with increased adjusted odds of myocardial infarction, heart failure, stroke and nephropathy in a nationally representative sample of USA adults with diabetes mellitus.

The association of RDW with nephropathy but not with neuropathy or retinopathy is likely to be due to differences in the pathophysiology of these microvascular complications in a diabetic population.

It has been suggested that the association with nephropathy may be mediated through oxidative stress, chronic inflammation and endothelial dysfunction Afonso et al., [13] . A possible explanation of the association of high RDW with diabetic nephropathy could be that a high RDW is a marker of altered glomerular haemodynamics.

Diabetic nephropathy is associated with red cell fragmentation Paueksakon et al., [20], which results in elevation of the RDW Banno et al., [21] Also Lewko and Stepinski [22] could explain increased sheer wall tension, resulted from intraglomerular hypertension is thought to be involved in the pathogenesis of diabetic nephropathy.

Such loss of deformability further predisposes to red cell fragmentation. Interestingly, a RDW above a threshold of $14 \%$ has recently been reported to be associated with decreased red cell deformability Patel et al., [23]. Loss of red cell deformability can also lead to impaired microvascular circulation and hypoxia as well as to micro thrombosis, all of which are thought to play an important role in the pathogenesis of diabetic nephropathy. However, these latter factors have been also been implicated in retinopathy and neuropathy. It may be that the interaction between raised intra glomerular pressure and lack of red cell deformability in particular leads to erythrocyte fragmentation and hence a high RDW Zalawadiya et al., [24] . Age of the patients, BMI and CRP had positive significant moderate correlation with RDW similar to our study, Vayá et al., [25] mentioned a significant strong correlation between RDW and BMI.

\section{Conclusions:}

- This study confirmed a strong relation between diabetics with macrovascular complications and RDW.

- RDW considered as early noninvasive low cost test give information about the early diagnosis of diabetes complications and facilitate decisionmaking in prevention and treatment.

- RDW has a role as a predictive marker of macrovascular complications in diabetes mellitus. So diabetic patients with raised level of RDW required close monitoring of risk factors.

\section{Recommendations:}

We would recommend a future study to detect the relation between RDW and microvascular complication in selected diabetic patients, as no published data till now were reported on the relationship.

Although the same mechanisms affect the pathogenesis of diabetic nephropathy and diabetic retinopathy, the changes in RBW was with diabetic nephropathy than those with retinopathy. So another study needed to clarify the exact pathogenesis. 
Fund: No fund has been received.

\section{Conflict of interest:}

No conflict of interest coud be declared.

\section{References}

1- American Diabetes Association. ADA.: Diagnosis and Classification of Diabetes Mellitus. Diabetes Care January, 36 (1): S67-S74, 2013.

2- American Diabetes Association. ADA.: "Diabetes Care" January 2010". Retrieved 2010-01-29, 2010.

3- CHEUNG N. and WONG T.Y.: Diabetic retinopathy and systemic vascular complications. Prog. Retin. Eye Res., 27: 161-76, 2008.

4- EVANS T. and JEHLE D.: The red blood cell distribution width. J. Emmerg. Med., 9 (1): 71-4, 1991.

5- BRIGGS C. AND BAIN B.J.: BASIC HAEMATOLOGICAL TECHNIQUES. BAIN B.J., BATES I., LAFFAN M., LEWIS S.M. DACIE and LEWIS: Practical Haematology. 11 th ed. Philadelphia, PA: Churchill Livingstone/ Elsevier. Chap. 3, 2012.

6- VAJPAYEE N., GRAHAM S.S., BEM S. BASIC EXAMINATION OF BLOOD, BONE MARROW. McPHERSON R.A. and PINCUS M.R.: Henry's Clinical Diagnosis and Management by Laboratory Methods. $22^{\mathrm{nd}}$. Elsevier/ Saunders: Philadelphia, PA. 30, 2011.

7- MAGRI C.J., FAVA S.: Red blood cell distribution width and diabetes-associated complications. Diabetes MetabSyndr., 8 (1): 7-13, 2014.

8- YAO H.M., SUN T.W., ZHANG X.J., SHEN D.L., DU Y.Y., WAN Y.D., ZHANG J.Y., LI L. and ZHAO L.S.: Red blood cell distribution width and long-term outcome in patients undergoing percutaneous coronary intervention in the drug-eluting stenting era: A two-year cohort study. PLoS One, 9 (4): 94887, 2014.

9- FERRUCCI L., GURALNIK J.M., WOODMAN R.C., BANDINELLI S., LAURETANI F., CORSI A.M., et al.: Proinflammatory state and circulating erythropoietin in persons with and without anemia. Am. J. Med., 118: 1288, 2005.

10- TONELLI M., SACKS F., ARNOLD M., MOYE L., DAVIS B. and PFEFFER M.: For the Cholesterol and Recurrent Events (CARE) Trial Investigators. Relation between red blood cell distribution width and cardiovascular event rate in people with coronary disease. Circulation, 117: 163-8, 2008

11- PATEL K.V., FERRUCCI L., ERSHLER W.B., LONGO D.L. and GURALNIK J.M.: Red blood cell distribution width and the risk of death in middle-aged and older adults. Arch. Intern. Med., 169: 515-23, 2009.

12- MALANDRINO N., WU W.C., TAVEIRA T.H., WHITLATCH H.B. and SMITH R.J.: Association between red blood cell distribution width and macrovascular and microvascular complications in diabetes. Diabetologia, 55: 226-35, 2012.
13- AFONSO, S.K. ZALAWADIYA, V. VEERANNA, S.S. PANAICH, A. NIRAJ and S. JACOB L.: Relationship between red cell distribution width and microalbuminuria: A population-based study of multiethnic representative US adults Nephron. Clin. Pract., 119 (4). pp. c277-c282, 2011.

14- MAGRI C.J.U. and FAVA S.: Red blood cell distribution width and diabetes-associated complications. Diabetes Metab. Syndr., 8 (1): 7-13, 2014.

15- CAKIR, LUTFULLAH, et al.: "Mean platelet volume increases in type 2 diabetesmellitusindependentof HBA1C level. Acta Medica., 30: 425, 2014.

16- KIM H.M., KIM B.S., CHO Y.K., KIM B.I., SOHN C.I., JEON W.K., KIM H.J., PARK D.I., PARK J.H., JOO K.J., KIM C.J., KIM Y.S., HEO W.J. and CHOI W.S.: Elevated red cell distribution width is associated with advanced fibrosis in NAFLD. Clin. Mol. Hepatol. Faculty, 1 (1): 55-63, 2015.

17- ANI C. and OVBIAGELE B.: Elevated red blood cell distribution width predicts mortality in persons with known stroke. J. Neurol. Sci., 277 (1-2): 8-103, 2009.

18- SHERIF H., RAMADAN N., RADWAN M., HAMDY E. and REDA R.: Red Cell Distribution Width as a Marker of Inflammation in Type 2 Diabetes Mellitus. Life Science Journal, 10 (3), 2013.

19- LEE Y.H. and PARTLEY R.E.: The evolving role of inflammation in obesity and the metabolic syndrome. Curr. Diab. Rep., 5: 70-5, 2005.

20- PAUEKSAKON, M.P. REVELO, L.J. MA, C. MARCANTONI and A.B. FOGO P.: Microangiopathic injury and augmented PAI-1 in human diabetic nephropathy Kidney Int, 61(June (6), pp. 2142-8, 2002.

21- BANNO Y., ITO C., TANAKA T., HORI K., FUJIMOTO T., SUZUKI S., et al.: Quantification of red blood cell fragmentation by the automated hematology analyzer XE2100 in patients with living donor liver transplantation Clin. Lab. Haematol., 27 October (5), pp. 292-6, 2005.

22- LEWKO and JAND STEPINSKI B.: Hyperglycemia and mechanical stress: Targeting the renal podocyte J. Cell Physiol., 221 (November (2)). pp. 288-95, 2009.

23- PATEL J.G., MOHANTY B., KANAPURU C., HESDORFFER W.B., ERSHLER J.M. and RIFKIND K.V.: Association of the red cell distribution width with red blood cell deformability Adv. Exp. Med. Biol., 765. pp. 211-6, 2012.

24- ZALAWADIYA S.K., VEERANNA V., PANAICH S.S., AFONSO L. and GHALI J.K.: Gender and ethnic differences in red cell distribution width and its association with mortality among low risk healthy United State adults. Am. J. Cardiol., Jun. 1, 109 (11): 1664-70. Epub. 2012 Mar 15. PubMed PMID: 22424582, 2012.

25- VAYÁ A., SARNAGO A., FUSTER O., ALIS R. and ROMAGNOLI M.: Influence of inflammatory and lipidic parameters on red blood cell distribution width in a healthy population. Clin. Hemorheol. Microcirc., 59: 379-85, 2015. 


\section{إختلاف آحجام كرات الدم الحمراء كعلامة للإلتهابات فى مرض كرات السكرى النوع النداء كعانى}

داء السكرى هو مجموعة هن الإضطرابات الآيضية التى تتميز بإرتفاع السكر فى الدم والذى ينتج من آى خلل فى إفراز الآنسولين، عمل الآنسولين آو كليهما.

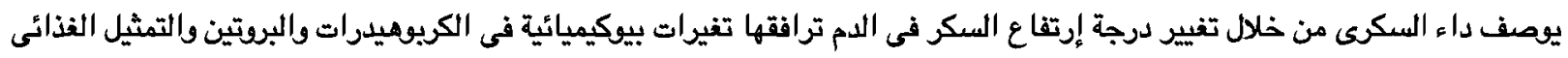

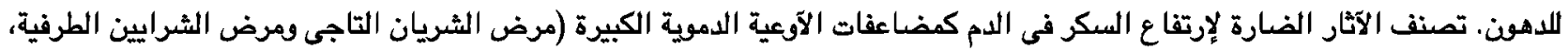

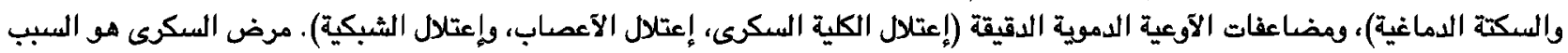

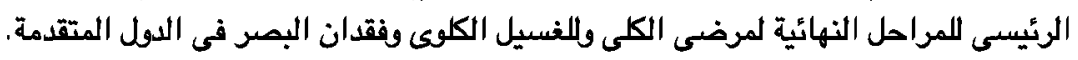

إختلاف آحجام كرات الدم الحمراء هو قياس التغير فى حجم تداول كريات الدم الحمراء (تفاوت الكريات) والتى يتم الحصول عليها بشكل

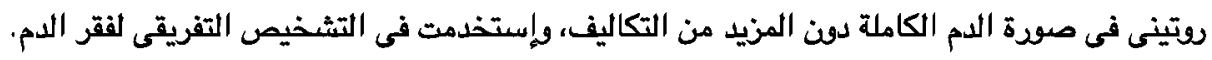

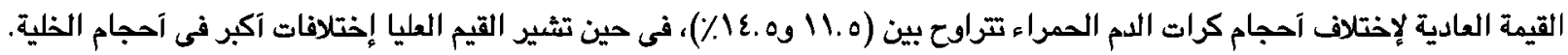

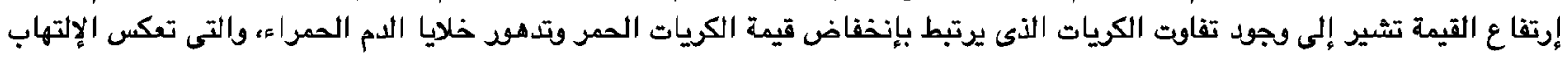
المزمن وزيادة مستوى الآكسدة. الهدف من الدراسة:

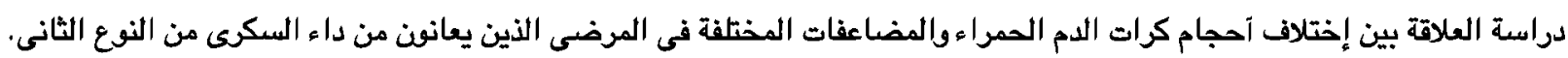
وعلاقتها بعلامة إلتهابات آخرى مثل البروتين سى التخام التفاعلى. نتيجة البحث:

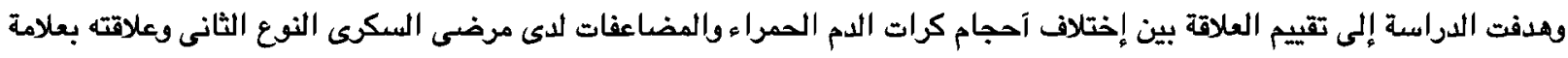

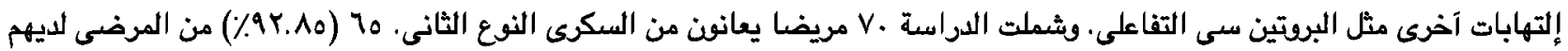

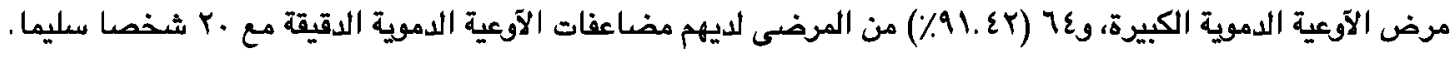

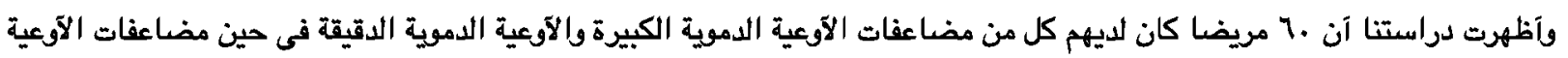

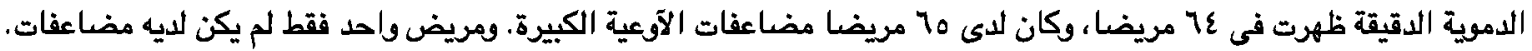

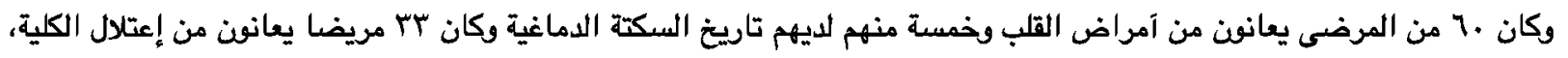

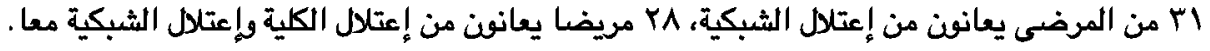

